\title{
Safety of Losartan in Hypertensive Patients with Thiazide Induced H yperuricemia
}

\author{
Moosa Khan, G hulam Rasool Mashori and Khalid Mustafa Memon
}

\begin{abstract}
OBJECTIVE: To determine the safety of Losartan in hypertensive patients with Thiazide induced hyperuricemia.

DESIGN: Randomized, open label, prospective, comparative study.

SETTING: Basic Medical Sciences Institute Jinnah Postgraduate Medical Centre Karachi from February 2006 to July 2006.

METHODS: Total 60 hypertensive hyperuricemic patients were enrolled in this study, selected from medical OPD of Jinnah Postgraduate Medical Centre, Karachi. Patients were divided in three groups. Group DR-1 patients were treated with Thiazide $50 \mathrm{mg} / \mathrm{day}$, Group DR-2 with Losartan + Thiazide 50 mg/day, and Group DR-3 with Losartan 50 mg/day. The effect on serum uric acid level was measured fortnightly.

RESULTS: Treatment with Thiazide + Losartan group DR-2 and Losartan group DR-3 significantly showed decrease in serum uric acid level. Whereas, Thiazide group DR-1 increased serum uric acid level. In contrast to Thiazide and Losartan + Thiazide, Losartan alone led to a greater reduction in serum uric acid level. The average percentage reduction in serum uric acid level in Thiazide + Losartan group was $-12.75 \%$ and the average percentage reduction of serum uric acid level was $\mathbf{- 2 4 . 6 0 \%}$ in Losartan group.

CONCLUSION: These finding suggest that, Losartan in hypertensive hyperuricemic patients is more effective drug in lowering serum uric acid level. It may be worth pointing out that the serum uric acid level lowering effect of Losartan might be particularly useful in hyperuricemic patients those on Thiazide diuretic (for hypertension and heart failure).
\end{abstract}

KEY WORDS: Hyperuricemia, Hypertension, Thiazide diuretic, Losartan.

\section{INTRODUCTION}

Elevated serum uric acid is closely associated with several painful conditions, such as gout, kidney stones, vascular disease, renal disease, and cardiovascular events ${ }^{1}$. Several epidemiological studies have identified an association between increased serum uric acid and cardiovascular risk in the general population and among patients with hypertension². Despite the strength of these associations uric acid seems inextricably linked to dyslipidemia and disordered glucose metabolism ${ }^{3}$. Elevated serum uric acid is present in $25 \%$ of untreated hypertensive subjects, in $50 \%$ of subjects taking diuretics and in $>75 \%$ subjects with malignant hypertension ${ }^{4}$. In addition diet, genetics or other influences are also important modulators of serum uric acid levels ${ }^{5}$.- Baseline serum uric acid was significantly associated with an increased rate of the composite outcome in the life study of cardiovascular death, fatal or non fatal myocardial infarction, and fatal or non fatal stroke $(P<.0001)^{2}$. Hyperuricemia is a strong predictor of stroke events in middle aged patients with NIDD independently of other cardiovascular risk factor- ${ }^{6}$. Gout is an acute, often recurrent arthritis mediated by the crystallization of uric acid in the joints and typically associated with elevated levels of serum uric acid ${ }^{5}$. In one study $72 \%$ of men with gout reported hyperuricemia ${ }^{7}$. On the other hand, there have been several studies that clearly indicated that increased serum urate might be an independent risk factor for hypertension associated morbidity and mortality ${ }^{1,8}$. While a specific relationship continues to be debated, there is considerable interest in the potential importance of serum uric acid in patients with Thiazide diuretic treated hypertensive patients and how to best treat them. Losartan an angiotensin II receptor antagonist, is an effective anti-hypertensive drug that also has a uricosuric effect due to its molecular disposition (or physical property) ${ }^{9}$. Losartan recently shown to target the urate anion exchange URATI and inhibit urate uptake by this transporter, thus reducing urate reabsorption from the proximal tubule, which is the main site of urati in the human kidney ${ }^{10}$. 


\section{PATIENTS AND METHODS}

This randomized, open label, prospective, comparative study was conducted in the Department of Pharmacology and Therapeutics, Basic Medical Sciences Institute (BMSI), Jinnah Postgraduate Medical Centre, Karachi in collaboration with other wards/OPD. Sixty hypertensive hyperuricemic patients were enrolled in this study, selected from medical OPD of Jinnah Postgraduate Medical Centre Karachi. The 57 patients remained associated through out the study period, whereas 3 patients were dropped due to failure of the follow-up period, among those 2 in Thiazide group and 1 in Losartan + Thiazide group. The research and ethics committee of our institution approved the study protocol. All the patients in the study were selected accordingly to the following criteria.

\section{Inclusion Criteria:}

Thiazide induced hyperuricemic hypertensive patients (serum uric acid level between 7.0 and $12.0 \mathrm{mg} / \mathrm{dL}$ of either sex, their ages ranging from 45 to 65 years.

\section{Exclusion Criteria:}

Secondary hypertension, history of gout and renal lithiasis with in the last two years, history of malignant hypertension, history of cerebrovascular accidents with in last two years, cardiac arrhythmia, clinically significant renal and hepatic impairment, pregnant and lactating women, history of neurological and mental disorder, patients using any drug that could affect serum uric acid level.

\section{Materials And Parameter:}

AT1 receptor blocker Losartan $50 \mathrm{mg}$

Thiazide diuretic $50 \mathrm{mg}$ (Hydrochlorothiazid)

Kit for uric acid (linear chemicals)

Disposable syringes

Blood samples from all patients at screening and follow up were analyzed for serum urate by the enzymatic colorimetric method. Laboratory tests were performed at screening and then fortnightly follow-up visits.

\section{Study Design:}

The selected patients were divided into three groups. Group or Drug-1 (DR 1) Thiazide

Twenty hypertensive hyperuricemic patients with above mention inclusion criteria were allocated tab. Thizide $50 \mathrm{mg} /$ day for 12 weeks

Group or Drug-2 (DR-2) Losartan+ Thiazide

Twenty hypertensive hyperuricemic patients with the same criteria were allocated Tab. Losartan $50 \mathrm{mg}+$ Thizide $50 \mathrm{mg}$ once daily for 12 weeks
Group or Drug-3 (DR 3) Losartan

Twenty hypertensive hyperuricemic patients with same criteria were provided Tab Losartan 50 mg/day for 12 weeks.

\section{Statistical Analysis:}

All the values were taken as mean and \pm SD. The primary efficacy measurement was the mean change in serum uric acid throughout the study period from the baseline to end point. To compare means and standard deviations of quantitative variables between three groups, Student t-test was used.

\section{RESULTS}

In this study, a total number of 60 patients were randomized, both sexes were enrolled. They were divided in three groups of 20 patients each and designated as group DR-1 (Thiazide), group DR-2 (Thiazide + Losartan) and group DR-3 (Losartan). All the patients ranged in age between 45 and 65 years. Our final analysis applied to 57 patients who completed the study protocol, as 3 patients were unable to complete the study. When end-study results of three groups were compared they showed significant changes effect in serum uric acid level as illustrated in Table I. When data of groups compared with each other, in group DR-3 Losartan $50 \mathrm{mg}$ once daily and group DR-2 Thiazide $50 \mathrm{mg}+$ Losartan $50 \mathrm{mg}$ once daily produced significant $(P<0.001)$ decrease in serum uric acid level. In group DR-3 (Losartan ) mean serum uric acid level decreased from $8.21 \pm 0.17 \mathrm{mg} / \mathrm{dL}$ on day 0 to $6.99 \pm 0.13 \mathrm{mg} / \mathrm{dL}$ on day 45 and to $6.19 \pm 0.11$ $\mathrm{mg} / \mathrm{dL}$ on day 90 . The reduction was statistically highly significant $(P<0.001)$ when compared between day 0 and day 45 between day 45 and day 90 and between 0 and day 90 . The average percentage reduction was $-24.6 \%$. In group DR-2 (Thiazide + Losartan) mean serum uric acid level decreased from $8.70 \pm 0.25 \mathrm{mg} / \mathrm{dL}$ at day 0 to $8.09 \pm 0.23 \mathrm{mg} / \mathrm{dL}$ on day 45 and $7.59 \pm 0.22 \mathrm{mg} / \mathrm{dL}$ on day 90 . The reduction was statistically highly significant $(P<0.001)$ when compared between day 0 and day 45 , between day 45 and day 90 , and day 0 and day 90 . The average percentage reduction was $-12.75 \%$ from day 0 to day 90 . In DR-1 group (Thiazide) mean serum uric acid level increased from $8.41 \pm 0.21 \mathrm{mg} / \mathrm{dL}$ on day 0 to $8.75 \pm 0.22 \mathrm{mg} / \mathrm{dL}$ on day 45 and to $9.01 \pm 0.20 \mathrm{mg} / \mathrm{dL}$. This increase in serum uric acid level was statistically highly significant $(p<0$.001) when compared between day 0 to day 45 and day 45 to day 90 . The average percentage increase in serum uric acid level 
FIGURE I:

PERCENTILE CHANGES IN SERUM URIC ACID LEVEL FROM DAY 0 TO DAY 90 OF TREATMENT WITH DR1, DR2 AND DR3 IN HYPERURICEMIC AND HYPERTENSIVE PATIENTS

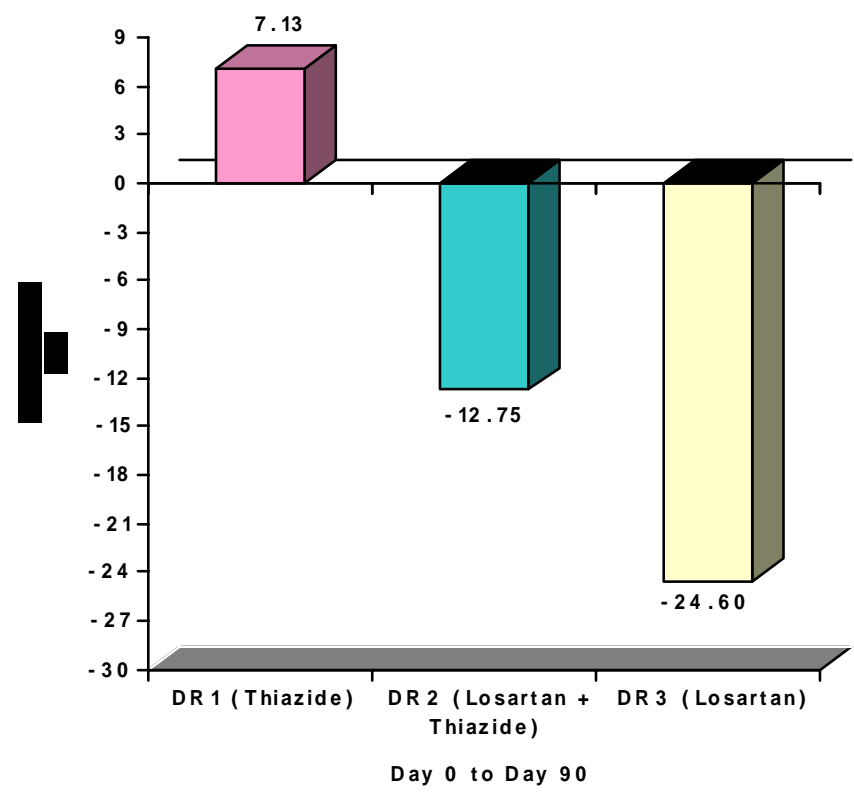

tan on serum uric acid with essential hypertension and elevated levels of serum uric acid. Losartan was first reported to decrease serum uric acid in a dose dependent manner with uricosuric properties and this study extends those findings in the Pakistani population. In the life study Losartan was shown to decrease the elevated levels of uric acid that hypertensive experience Losartan attenuated the increase in serum uric acid by comparison to the atenolol treated group over the entire duration of study of 4.8 years $(P<0.001)$. In life study, baseline serum uric acid was significantly associated with increased cardiovascular risk $^{1}$. In a secondary analysis of the life study, it was shown that $29 \%$ of the reduction in the composite outcome measure (cardiovascular death, $\mathrm{Ml}$ and stroke) in the Losartan group could be explained by the difference in serum uric acid over the course of the study $(P=0.004)^{2}$. These results suggest that the unique uricosuric quality of Losartan may be an added benefit of this particular angiotensin receptor blocker. Previously, it was shown that Losartan induced a significant decrease in serum uric acid levels in patients

TABLE I:

CHANGE IN MEAN SERUM URIC ACID LEVEL FROM DAY 0-DAY 45, DAY 45-DAY 90 AND DAY 0-DAY 90 OF TREATMENT WITH DR1, DR2 AND DR3 IN HYPERTENSIVE HYPERURICEMIC PATIENT

\begin{tabular}{|c|c|c|c|c|c|c|}
\hline Groups & At Day 0 & At Day 45 & At Day 90 & \multicolumn{3}{|c|}{ P Value } \\
\cline { 4 - 7 } & & & D0-D45 & D45-D90 & D0 - D90 \\
\hline DR1 & $\begin{array}{c}8.41 \pm 0.21 \\
(\mathrm{n}=20)\end{array}$ & $\begin{array}{c}8.75 \pm 0.22 \\
(\mathrm{n}=18)\end{array}$ & $\begin{array}{c}9.01 \pm 0.20 \\
(\mathrm{n}=18)\end{array}$ & $<0.001$ & $<0.001$ & $<0.001$ \\
\hline DR2 & $\begin{array}{c}8.70 \pm 0.25 \\
(\mathrm{n}=20)\end{array}$ & $\begin{array}{c}8.09 \pm 0.23 \\
(\mathrm{n}=20)\end{array}$ & $\begin{array}{c}7.59 \pm 0.22 \\
(\mathrm{n}=19)\end{array}$ & $<0.001$ & $<0.001$ & $<0.001$ \\
\hline DR3 & $\begin{array}{c}8.21 \pm 0.17 \\
(\mathrm{n}=20)\end{array}$ & $\begin{array}{c}6.99 \pm 0.13 \\
(\mathrm{n}=20)\end{array}$ & $\begin{array}{c}6.19 \pm 0.11 \\
(\mathrm{n}=20)\end{array}$ & $<0.001$ & $<0.001$ & $<0.001$ \\
\hline
\end{tabular}

The concentration was measured in $\mathrm{mg} / \mathrm{dL}$ figure in parentheses indicate number of patients.

Key

DR1 = Thiazide

DR2 = Losartan + Thiaezid

DR3 = Losartan

Figures are in (mean \pm SD)

\section{DISCUSSION}

In current study, we conducted a comparative clinical trial to evaluate the effect of Losartan on serum uric acid in hypertensive patients with Thiazide induced hyperuricemia in Pakistani population, the primary objective of this study was to see the effect of Losar- with hypertension, elevated levels of serum uric acid, and gout. They found that increasing the dose of Losartan from $50 \mathrm{mg}$ once daily to twice a day did not further reduce serum uric acid levels ${ }^{9}$. In a similar study of Asian men with gout and hypertriglyceridemia or hypertension, the addition of Losartan to allopurinol $(p<0.01)$ caused a significant decrease in serum uric acid ${ }^{11}$. In the present study Losartan treatment induced a significant decrease in serum uric acid levels in Pakistani patients with hypertension and high levels of uric acid, which is in agreement with the results reported by several others ${ }^{9-11}$. The study of Takahashi et al, showing reduction of $11 \%$ in serum uric acid 
level in combination therapy i.e. Losartan and allopurinol and $15 \%$ reduction in serum uric acid level, Losartan alone decreased serum uric acid by $13 \%$. The result of this study correlates with Takahashi in respect of monotherapy i.e. Losartan ${ }^{11}$. Our results are also in favor of Weber et al, who concluded that mean values of serum uric acid reduced by Losartan at baseline ( $0.44 \mathrm{mmol} / \mathrm{l}$ to $0.39 \mathrm{mmol} / \mathrm{l}$ ) after 24 hours. Our study matches with the study of Weber ${ }^{13}$. Our observations of DR-2 group and DR-3 group regarding serum uric acid reduction supported by the study of Bardin showing that Losartan increased urinary uric acid excretion up to $30 \%$ and was observed $15 \%$ reduction in mean serum uric acid level by Losartan ${ }^{10}$. Minghelli et al, evaluates the uricosuric effect of Losartan in hypertensive patients with hyperuricemia and concluded that plasma uric acid levels decreased significantly after 4 weeks of treatment with Losartan $(P<0.05)$ a significant increase in uric acid excretion was observed only with Losartan support our result ${ }^{14}$. Our observations of DR-2 group and DR-3 group regarding serum uric acid level are also supported by the study of Alice et al, that showed Losartan decreased serum uric acid in cyclosporin induced hyperuricemia in hypertensive patients and was observed reduction in mean serum uric acid level at baseline $7.8 \mathrm{mg} / \mathrm{dL}$ to $7.3 \mathrm{mg} / \mathrm{dL}$ at week 3 by Losartan ${ }^{12}$. Since serum urate is elevated in renal dysfunction or inappropriate diet and may be marker for cardiovascular disease and a Thiazide is often co-prescribed with Losartan, the uricosuric effect of Losartan may be useful to counter-act any rise in urate or increase in risk of gout. Losartan has no indication for the treatment of elevated levels of serum uric acid, but is indicated for the treatment of hypertension. Several studies have indicated that increased serum might be an independent risk factor for hypertension-associated morbidity and mortality, so Losartan may be a good option in hypertensive patients with elevated levels of serum uric acid.

\section{CONCLUSION}

It may be worth pointing out that uricosuric effect of Losartan might be particularly useful in patients those on Thiazide diuretic (for hypertension and heart failure). Losartan might be a useful therapeutic tool to control blood pressure and reduce serum uric acid levels in hypertensive patients. And we can prescribe Thiazide in combination with Losartan in patients having hyperuricemia, hypertension and gout.

\section{REFERENCES}

1. Johnson RJ, Kang DH, Feig D, Kirlighn S, Kanellis $\mathrm{j}$. is there a pathogenetic role for uric acid in hypertension and cardiovascular and renal disease? Hypertension 2003; 41(6):1183-90.

2. Hoieggen. The impact of serum uric acid on cardiovascular outcome. Kidney International 2004; 65: 1041-9.

3. Culleton BF, Larson MG, Kennel WB, Levy D. Serum uric acid and risk for cardiovascular disease and death: the framinghan heart study. Ann Intern Med 1999; 131:7-13.

4. Dang A, ZhangY, Chen G, Song W, Wang B. Effect of Losartan and irbesartan on serum uric acid in hypertensive patients with hyperuricemia in Chinese population. J Human Hypertension 2006; 20: 45-50.

5. Johnson RJ, Radeont BA. Uric acid and dietinsight into the epidemic of cardiovascular Disease. N Eng J Med 2004; 350(11):1071-3.

6. Lehto S, Niskanan L, Tapari. Serum uric acid is strong predictor of stroke in patients with non insulin Dependent Diabetes mellitus. Stroke 1998; 29:635-9.

7. Choi HP. Urine rich foods, dairy and protein intake the and risk of gout in men. New Eng J Med 2004; 350:1093-103.

8. Weri CJ, Muri SW, Walters MR, Lees KR. Serum urate as independent predictor of poor out-come and future vascular events after acute stroke. 2003; 34(8):1951-6.

9. Wurzner G, Gester JG, Chiolero A, Maillard M, Stubi F, Brunner HR. Comparative effects of Losartan and irbesartan on serum uric acid in hypertensive patients with hyperuricemia and gout. $\mathrm{J}$ Hypertens 2001; 19(10):1855-60.

10. Bardin T. Fenofibrate TB, and Losartan. Ann Rheum 2003; 62: 497-8.

11. Takahashi S, Moriwaki Y, Yamamoto T, Tsutsumi $Z$, Ka T, Fukuchi M. Effect of combination treatment using anti hyperuricemic agents with fenofibrate and/or Losartan on uric acid metabolism. Ann Rheum Dis 2004; 62(6):572-5.

12. Schmidt A, Gruber U, Bohmig G, Koller E, Mayer $G$. The effect of ACE inhibitor and angiotensin II receptor antagonist therapy on serum uric levels and potassium homeostasis in hypertensive renal transplant recipients treated with CsA. Nephrol Dial Transplant 2001; 16:1034-7. 
13. Weber AM, Byyny $R L$, Pratt $H$, Elizabeth $P$, Faison P, Duane B, et al. Blood Pressure Effects Of the Angiotensin II Receptor Blocker, Losartan. Arch Intern Med 1995;155:405-11.
14. Mingheli G, Seydoux C, Goy J, Burnier M. Uricosuric effect of the angiotensin II receptor antagonist Losartan in heart transplant recipients. Transplantation 1998; 66(2):268 -71.

AUTHOR AFFILIATION:

Dr. Moosa Khan (Corresponding Author)

Department of Pharmacology \& Therapeutics

Basic Medical Sciences Institute

Jinnah Post Graduate Medical Centre, Karachi

Dr. Ghulam Rasool Mashori

Department of Pharmacology \& Therapeutics

Basic Medical Sciences Institute

Jinnah Post Graduate Medical Centre, Karachi

Dr. Khalid Mustafa Memon

Department of Pharmacology

Sir Sayyed Medical College Karachi 